\title{
APLIKASI NILAI UJIAN BERBASIS SMS GATEWAY PADA MADRASAH ALIYAH NEGERI 1 HALMAHERA TENGAH
}

\section{THE APPLICATION VALUE OF TEST-BASED SMS GATEWAY AT MADRASAH ALIYAH NEGERI 1 CENTRAL HALMAHERA}

\author{
Jupri $^{1}$, Arisandy Ambarita ${ }^{2}$ \\ Program Studi Manajemen Informatika \\ Politeknik Sains dan Teknologi Wiratama Maluku Utara \\ jupri18@gmail.com
}

\begin{abstract}
Abstrak
Madrasah Aliyah Negeri (MAN) 1 Halmahera Tengah merupakan lembaga pendidikan yang bertugas menangani kegiatan-kegiatan pendidikan, salah satunya dalam menginformasikan nilai akademik siswa pada ujian UTS dan UAS, informasi nilai akhir ujian UTS dan UAS di informasikan pada saat akhir masa pembelajaran sehingga orang tua atau wali yang ingin memantau nilai ujian UTS dan UAS saat itu harus datang untuk mengetahui informasi nilai ujian, sehingga dianggap kurang efisien, Penilitian ini dilakukan di Madrasah Aliyah Negeri (MAN) 1 Halmahera Tengah, Metode analisa sistem yang digunakan adalah Model Driven secara terstruktur yaitu menggambar model sistem yang berjalan dan diusulkan menggunakan alat bantu flowchart dengan pendekatan bottom-up, sedangkan Model Pengembangan Sistem menggunakan model Waterfall dan model Uji sistem menggunakan Blackbox, Alat bantu Rancangan Sistem menggunakan DFD, ERD dan Tabel Database. Sistem ini menggunakan aplikasi gaтmu yang tampilan interfacenya menggunakan bahasa pemrograman $H T M L, P H P, M Y S Q L$, dengan adanya sistem ini diharapkan dapat membantu pihak sekolah dalam menyampaikan informasi nilai UTS dan UAS dan pihak orang tua dapat melihat informasi nilai UTS dan UAS dengan menggunakan sms saat itu tanpa harus datang ke sekolah tersebut
\end{abstract}

\section{Kata kunci: Aplikasi, Nilai Ujian, SMS Gateway}

\begin{abstract}
Madrasah Aliyah Negeri (MAN) 1 Central Halmahera is an educational institution in charge of handling educational activities, one of which is in informing students' academic value in the UTS and UAS exams, information on the final grades of the UTS and UAS exam is informed at the end the learning period so that parents or guardians who want to monitor the UTS and UAS exam scores at that time must come to find out the exam score information, so that it is considered inefficient. This research was conducted at Madrasah Aliyah Negeri (MAN) 1 Central Halmahera, a system analysis method Structured Model Driven used is drawing a running system model and proposed using a flowchart tool with a bottom-up approach, while the System Development Model uses the Waterfall model and the System test model using Blackbox, Design System tools use DFD, ERD and Database Tables. This system uses the Gammu application which displays the interface using HTML, PHP, MySQL programming languages, with this system expected to help the school in conveying
\end{abstract}


information on UTS and UAS exam scores and the parents can see the information on UTS and UAS exam scores by using SMS when that without having to come to the school

\section{Keywords: Application, Exam Scores, SMS Gateway}

\section{PENDAHULUAN}

Perkembangan teknologi informasi membuat berbagai aktivitas dalam kehidupan manusia mengalami evolusi. Berbagai aktivitas mengalami perubahan dari cara konvensional yang praktiknya dilakukan secara manual menjadi cara modern yang umumnya sudah berbentuk digital.

Masyarakat banyak menggunakan cara modern karena menawarkan kecepatan, otomatisasi dan kemudahan dalam melakukan berbagai kegiatan sehari-hari, hal tersebut menyebabkan dituntut adanya teknologi dan perangkat elektronik yang lebih mudah dan bermanfaat dalam penggunaanya, karena kegiatan yang biasanya dilakukan di luar rumah, dapat dengan mudah dilakukan di dalam rumah dengan santai dan nyaman, contoh salah satu diantaranya ialah teknologi SMS gateway.

SMS gateway merupakan sebuah sistem aplikasi yang dipergunakan untuk mengirim atau menerima sms untuk keperluan bisnis, broadcast, promosi dan penyampaian informasi berupa produk maupun jasa kepada orang lain. Penggunaan SMS gateway ini penerapanya banyak dengan menggunakan GAMMU sebagai perangkat lunaknya. Untuk menggunakan SMS gateway tentunya menggunakan ponsel maupun modem baik GMS maupun CDMA yang digunakan sebagai server/media pengiriman dan penerimaan SMS (Heru Supriono, dkk)

Selain itu SMS merupakan metode store and forward sehingga keuntungan yang didapat adalah pada saat telepon seluler (Handphone) penerima tidak dapat dijangkau, tidak aktif atau diluar service area, penerima tetap dapat menerima SMS apabila telepon seluler sudah aktif kembali. Salah satu nya dapat digunakan pada proses penyampaian informasi nilai siswa di sekolah atau raport pada Madrasah Aliyah Negeri (MAN) 1 Halmahera Tengah

Madrasah Aliyah Negeri (MAN) 1 Halmahera Tengah merupakan lembaga pendidikan yang bertugas menangani kegiatan-kegiatan yang berkaitan dengan pendidikan salah satunya dalam menginformasikan nilai akademik siswa UTS dan UAS, dimana informasi nilai akhir ujian UTS dan UAS siswa di informasikan pada saat akhir masa pembelajaran dan orang tua atau wali yang ingin memantau nilai ujian UTS dan UAS saat itu harus datang untuk mengetahui informasi nilai ujian tersebut, sehingga dianggap kurang efisien dan memerlukan satu sistem yang dapat menjembatani orang tua atau wali siswa untuk dapat mengetahui nilai ujian siswa saat itu dan informasi nilai kepada orang tua siswa, yang memungkinkan pihak sekolah juga dapat untuk mengaksesnya dimanapun dan kapanpun

Untuk mengatasi masalah tersebut, maka dianggap perlu menerapkan "Aplikasi Informasi Nilai Siswa Berbasis SMS Gateway pada Madrasah Aliyah Negeri 1 Halmahera Tengah". Sistem ini menggunakan SMS Gateway dengan aplikasi gammu yang tampilan interfacenya berbasis Web dengan bahasa pemrograman HTML, PHP dan MySQL, dengan adanya sistem ini diharapkan dapat membantu pihak sekolah dalam 
menyampaikan informasi nilai UTS dan UAS saat itu dan pihak orang tua dapat melihat informasi nilai UTS dan UAS dengan menggunakan sms saat itu tanpa harus datang ke sekolah tersebut

\section{Rumusan Masalah}

Berdasarkan latar belakang tersebut, maka rumusan masalah penelitian ini adalah bagaimana merancang aplikasi informasi nilai akademik siswa berbasis sms gateway pada MAN 1 Halmahera Tengah, agar dapat membantu pihak sekolah dalam menyampaikan informasi nilai UTS dan UAS serta pihak orang tua dapat melihat informasi nilai dengan sms saat itu tanpa harus datang ke sekolah tersebut

\section{LANDASAN TEORI \\ Pengertian Aplikasi}

Menurut Sutabri (2012:147), aplikasi adalah alat terapan yang difungsikan secara khusus dan terpadu sesuai kemampuan yang dimilikinya

Menurut Indrajani (2015), aplikasi adalah program yang menentukan aktivitas pemrosesan informasi yang dibutuhkan untuk menyelesaikan tugas-tugas khusus dari pemakai komputer.

\section{Pengertian Informasi}

Menururt Sunyoto (2014), menjelaskan, informasi adalah data yang telah diolah menjadi sebuah bentuk yang berarti bagi penerimanya dan bermanfaat dalam mengambil keputusan saat ini atau mendatang

\section{Manfaat Informasi}

Informasi itu sangat beragam, baik dalam jenis, tingkatan maupun bentuknya. Manfaat informasi bagi setiap orang berbeda-beda. Adapun manfaat dari informasi menurut Sutanta (2003:11) adalah :

1. Menambah pengetahuan: Adanya informasi akan menambah pengetahuan bagi penerima yang dapat digunakan sebagai bahan pertimbangan yang mendukung proses pengambilan keputusan.

2. Mengurangi ketidakpastian pemakai informasi: Informasi akan mengurangi ketidakpastian karena apa yang akan terjadi dapat diketahui sebelumnya, sehingga kemungkinan menghindari keraguan pada saat pengambilan keputusan.

3. Mengurangi resiko kegagalan: Adanya informasi akan mengurangi resiko kegagalan karena apa yang akan terjadi dapat diantisipasi dengan baik, sehingga kemungkinan terjadinya kegagalan akan dapat dikurangi dengan pengambilan keputusan yang tepat.

4. Mengurangi keanekaragaman yang tidak diperlukan: Mengurangi keanekaragaman yang tidak diperlukan akan menghasilkan keputusan yang lebih terarah.

5. Memberikan standar, aturan-aturan, ukuran-ukuran, dan keputusan untuk menentukan pencapaian, sasaran dan tujuan.

\section{SMS Gateway}

SMS Gateway memungkinkan untuk sebuah pesan dapat di kirimkan dari sebuah aplikasi melalui jaringan operator telekomunikasi untuk di kirimkan ke nomor nomor tujuan. Dengan menggunakan aplikasi SMS Gateway, sumber data bisa didapatkan langsung dari basis data untuk selanjutnya di olah menjadi informasi dan dikirimkan secara sistemik / tanpa manual kepada banyak 
nomor dalam satu waktu". (Fahrudin, 2012).

\section{Kebutuhan SMS Gateway}

Menurut agus (2011:13), dalam membuat aplikasi berbasis SMS Gateway, hal lain yang perlu dipersiapkan selain kebutuhan utama (perangkat PC dan PHP Server) adalah :

\section{Handphone}

Modem/handphone berguna sebagai perantara terhubungnya koneksi aplikasi SMS yang akan digunakan dalam perangkat PC. Handphone ini dijadikan sebagai alat untuk mengirim pessan.

\section{Modem}

Modem merupakan sebuah perangkat keras yang berfungsi untuk komunikasi dua arah yang merubah sinyal digital menjadi sinyal analog atau sebaliknya untuk mengirimkan pesan/data ke alamat yang dituju.

3. Kabel Data

Kabel data berfungsi untuk menghubungkan perangkat mobile dengan perangkat PC.

4. Kartu SIM (Subscriber Identification Modul)

Kartu sim berfungsi sebagai operator jaringan seluler dan menyimpan identitas ponsel pelanggan dan digunakan untuk mengidentifikasi dan mengotentikasi pelanggan pada perangkat telepon seluler (seperti ponsel dan komputer).

\section{Pengertian Gammu}

Menurut Adiyanto, Suraya, dan Edhy (2013:51), “GAMMU adalah sebuah aplikasi/daemon yang dikhususkan untuk membangun sebuah SMS Gateway yang menghubungkan antara operator seluler ke internet dan sebaliknya. Aplikasi ini bersifat open source dibawah lisensi GPL."

\section{Pengertian $X A M P P$}

Menurut Nugroho (2013:1), XAMPP adalah paket program web lengkap yang dapat Anda pakai untuk belajar pemrograman Web, khususnya $P H P$ dan $M y S Q L$, paket ini dapat di download secara gratis dan legal

\section{Pengertian $\boldsymbol{P H P}$}

Menurut Nugroho (2013:153), "PHP kepanjangan dari Hypertext Preprocessor itu bahasa pemrograman berbasis web. Jadi, PHP itu adalah bahasa program yang digunakan untuk membuat aplikasi berbasis web (website, blog, atau aplikasi web)."

\section{MySQL}

MySQL adalah salah satu jenis database server yang sangat terkenal dan banyak digunakan untuk membangun aplikasi web yang menggunakan database sebagai sumber dan pengelolaan datanya" (Arief, 2011:151).

\section{Flowchart}

Menururt Indrajani (2015:36), “Flow chart adalah penggambaran secara grafik dari langkah-langkah dan urutan prosedur suatu program."

\section{DFD (Data Flow Diagram)}

Menurut Sukamto (2014:288), "Data Flow Diagram atau dalam bahasa Indonesia menjadi Diagram Alir Data (DAD) adalah refresentasi grafik yang menggambarkan aliran informasi dan transformasi informasi yang diaplikasikan sebagai data yang mengatur dari masukan (input) dan keluaran (output). DFD tidak sesuai untuk memodelkan sistem yang 
menggunakan pemograman berorientasi objek".

\section{METODE PENELITIAN}

Penelitian ini dilakukan pada MAN 1 Halmahera Tengah. Selama 2 bulan

Metode pengumpulan data yang dilakukan dalam penelitian ini adalah:

a. Observasi

Mengamati cara-cara pengisian nilai akademik pada lembaran raport yang dilakukan oleh operator sekolah.

b. Wawancara

Melakukan wawancara dengan kepala sekolah dan kepala tata usaha mengenai proses penginputan nilai dan penyerahan raport.

c. Dokumentasi

Mengumpulkan data-data sekunder yang berhubungan dengan proses penginputan nilai akademik demi memudahkan peneliti dalam proses perancangan dan desain sistem

\section{Alat dan Bahan yang digunakan}

a. Leptop ACER

b. Processoor Intel(R) Atom(TM) CPU N570@1.66GHz

c. Ram 2,00 GB

d. Hardisk $500 \mathrm{~GB}$

e. Printer Cannon ip 2870s.

f. Modem HUAWEI E3131

g. Windows 7 Professional 64 Bit

h. Microsoft Office 2007

i. Gammu

j. Xampp 1.8.2

k. HtmlPad 2015 dan 2016

1. Notepad ++

\section{Metode Analisa dan Pengembangan} Sistem

Metode yang digunakan pada analisa sistem yaitu Model Driven secara terstruktur yaitu menggambar model sistem yang berjalan dan diusulkan menggunakan alat bantu flowchart dengan pendekatan bottom-up sedangkan Model Pengembangan Sistem menggunakan model Waterfall

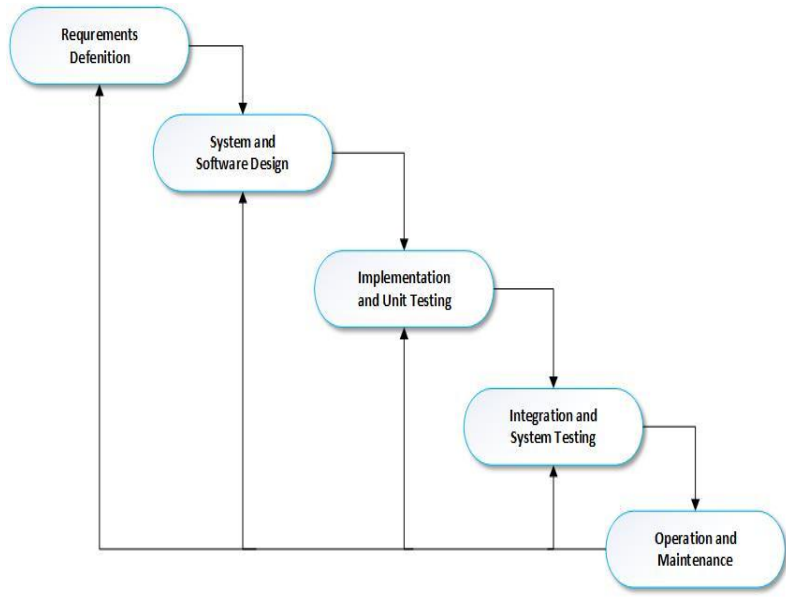

Gambar 1. Metode Waterfall (Sumber : Muharto dan Arisandy)

Berikut merupakan tahapan pengembangan sistem

a. Perencanaan dan Analisis: merencanakan tahapan, jadwal dan menganalisis kebutuhan sistem dalam membangun aplikasi SMS Gateway.

b. Desain dan Pengembangan sistem secara umum ini digambarkan dengan pada flowchat dan selanjutnya perancangan rinci input, proses dan output menggunakan $D F D, E R D$ dan Relation Table serta user interaface aplikasi.

c. Pembuatan kode program/Coding: adalah pokok dari proses pembuatan program itu dengan menggunakan bahasa pemrograman HTML, CSS, MySQL.

d. Pengujian/Testing: Pada tahap ini sistem yang telah dibangun di ujicoba, Metode uji menggunakan Blackbox Testing dan aplikasi yang sudah dibangun dijalankan dengan Aplikasi Gammu yang terhubung pada modem HUAWEI E3131, diujicobakan pada 
aplikasi Xampp dengan melakukan testing SMS yang dikirimkan dari hp

e. Pemeliharaan/ Maintenance: Pada tahap ini sebenarnya bagaimana program yang telah dibuat dan testing ini bekerja sebagaimana mestinya, update program, menyeselaikan bug yang tidak ditemukan pada saat testing, serta pengembangan yang dapat dilakukan dengan program tersebut.

\section{Analisa Sistem yang Berjalan}

Analisa sistem yang berjalan adalah tahapan indetifikasi masalah sistem yang digambarkan pada flowchart sebagai berikut:

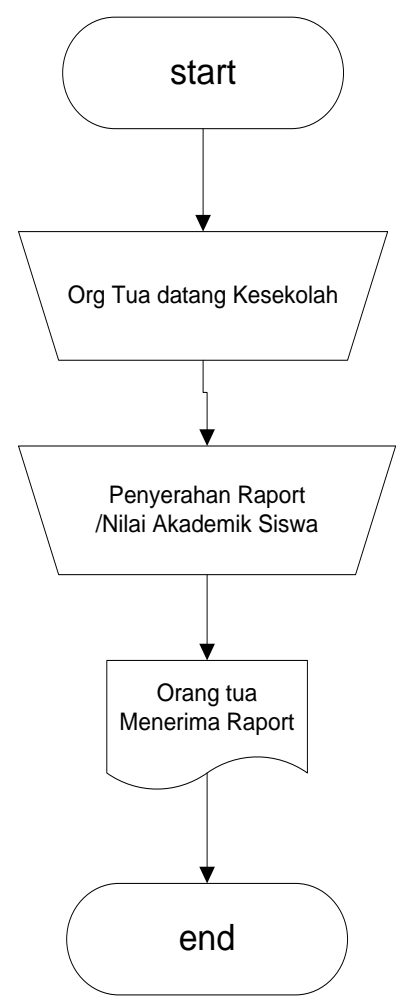

Gambar 2. Sistem yang berjalan

\section{Rancangan System yang Diusulkan}

Rancangan usulan sistem merupakan rancangan umum sistem yang dibuat untuk mengganti sistem yang lama. Berikut desain sistem yang diusulkan.

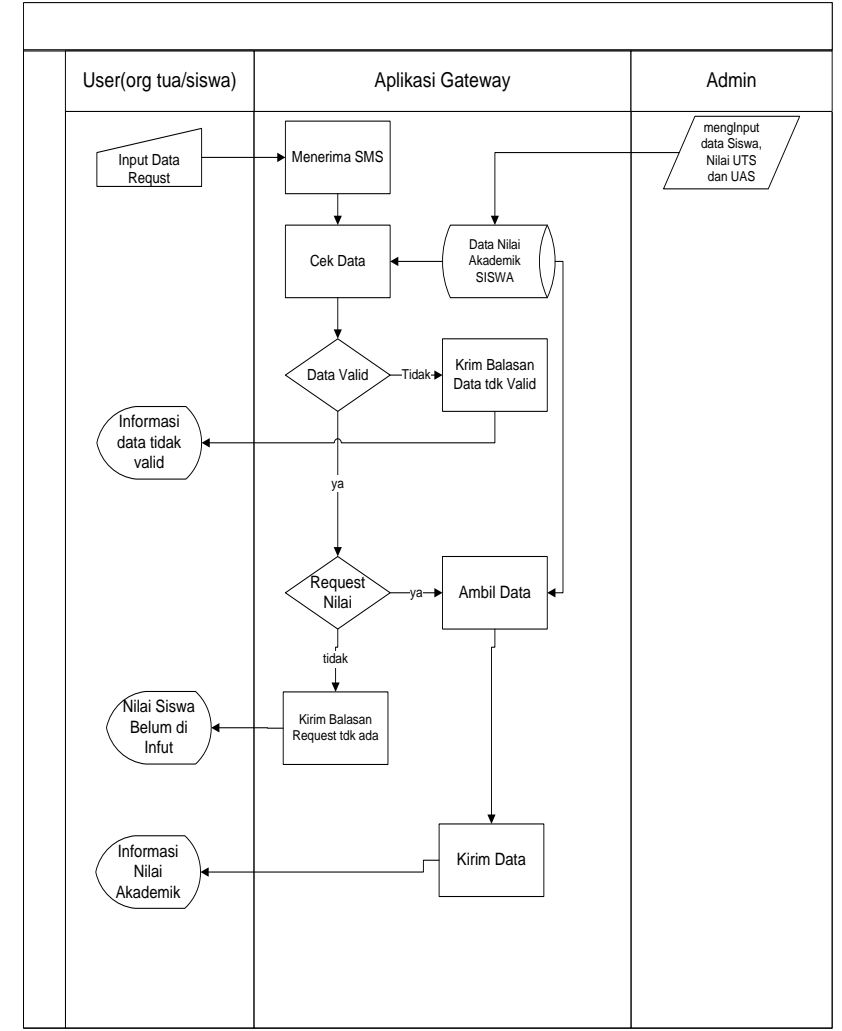

Gambar 3. Sistem Yang Diusulkan

\section{PERANCANGAN SISTEM}

Menurut Deni Darmawan dan Kunkun Nur Fauzi (2013:228), perancangan sistem adalah sebuah proses yang menentukan bagaimana suatu sistem akan menyelesaikan apa yang mesti diselesaikan.

\section{Rancangan Tabel Login}

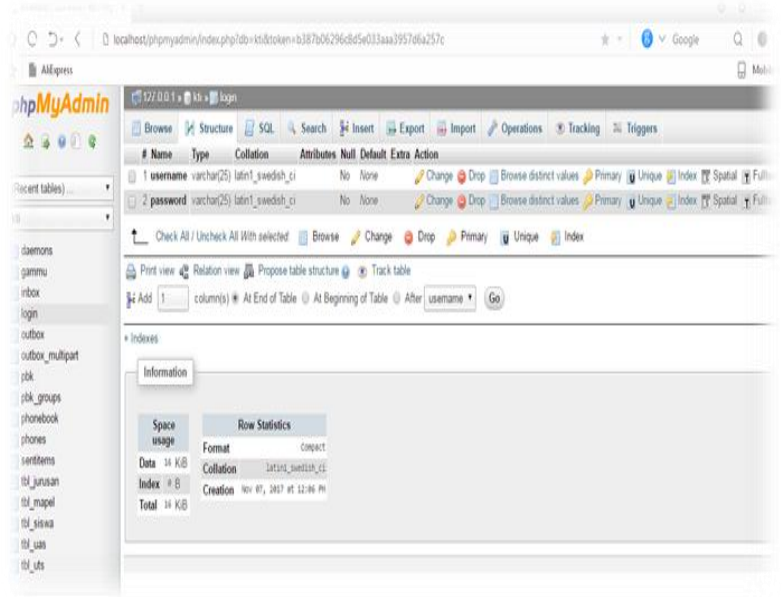

Gambar 4. Rancangan Tabel Login 


\section{Perancangan Tabel Mata Pelajaran}

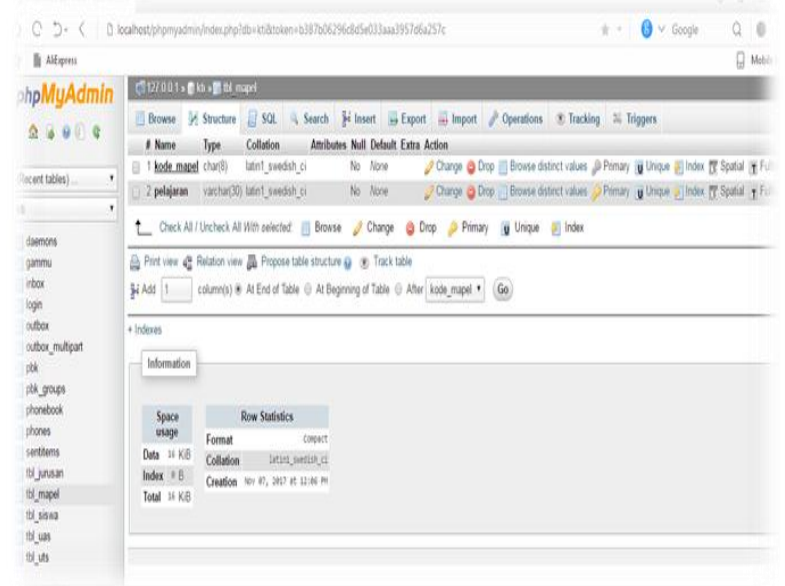

Gambar 5. Rancangan Tabel MP

\section{Perancangan Tabel Siswa}

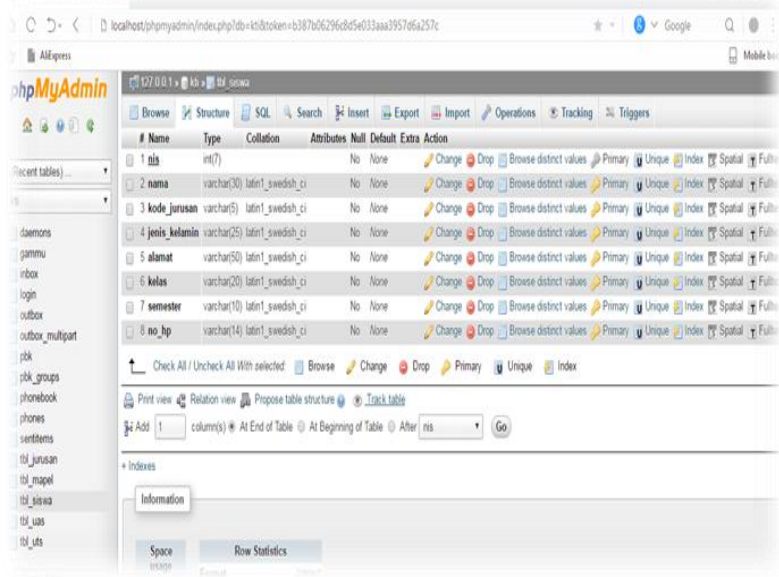

Gambar 6. Rancangan Tabel Siswa

\section{Perancangan Tabel Nilai UTS}

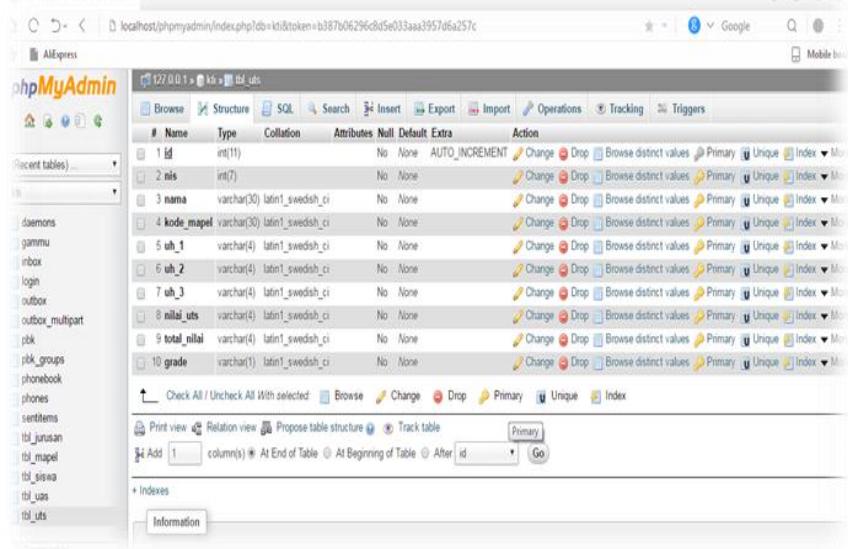

Gambar 7. Rancangan Tabel Nilai UTS

\section{Perancangan Tabel Nilai UAS}

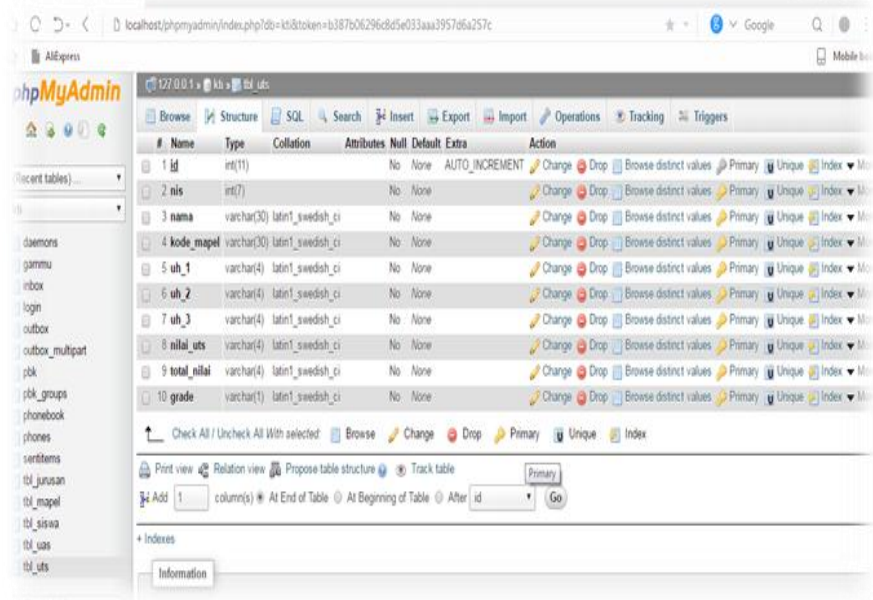

Gambar 8. Rancangan Tabel Nilai UTS

\section{Perancangan Tabel Inbox}

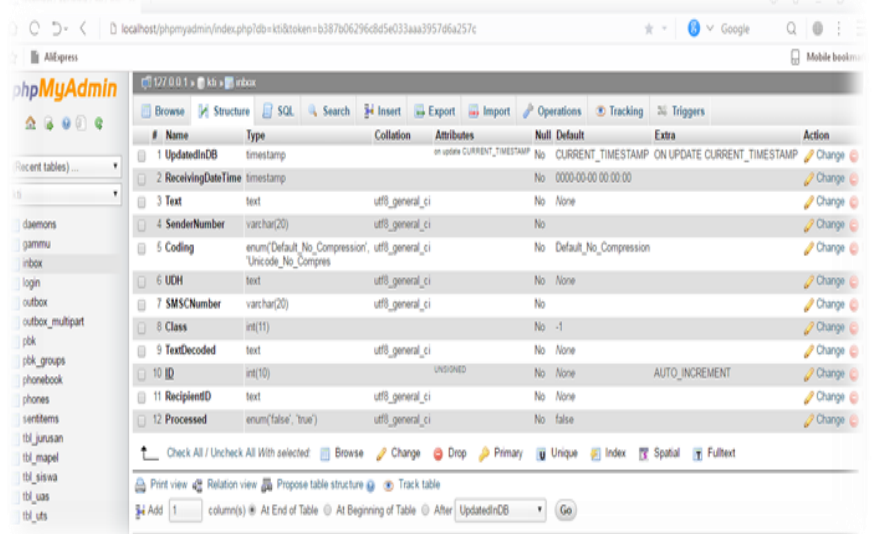

Gambar 9. Rancangan Tabel Inbox

\section{Perancangan Tabel Outbox}

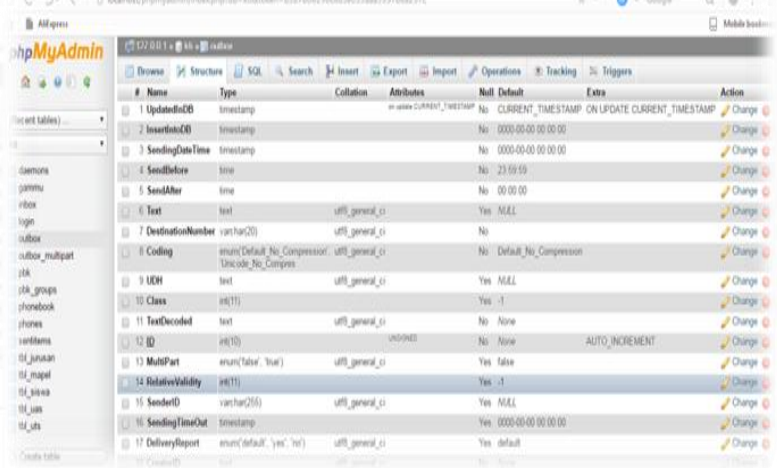

Gambar 10. Rancangan Tabel Outbox

\section{Diagram Konteks}


Diagram konteks merupakan diagram rancangan sistem secara umum, pada diagram konteks terdapat external entity, proses dan alur yang terhubung pada external entity dan proses, nerikut merupakan rancangan diagram konteks:

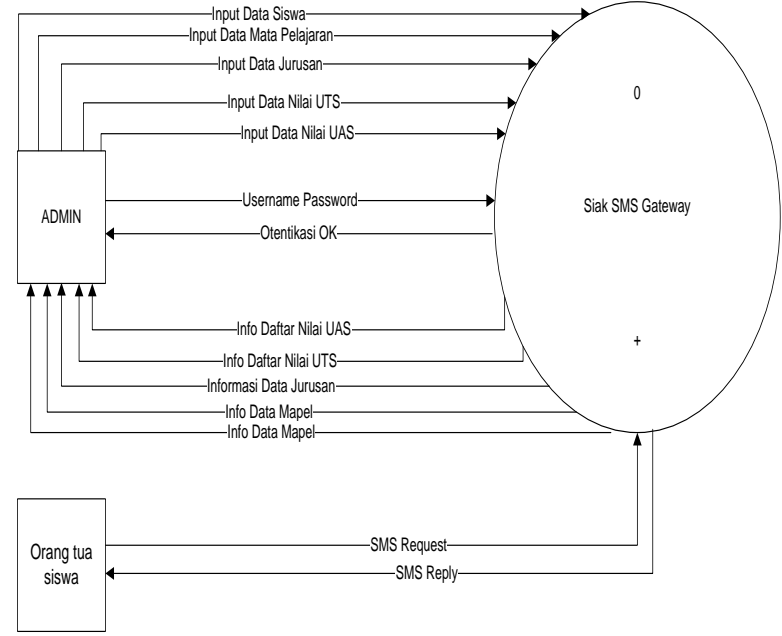

Gambar 11. Diagram Konteks

\section{DFD Level 1}

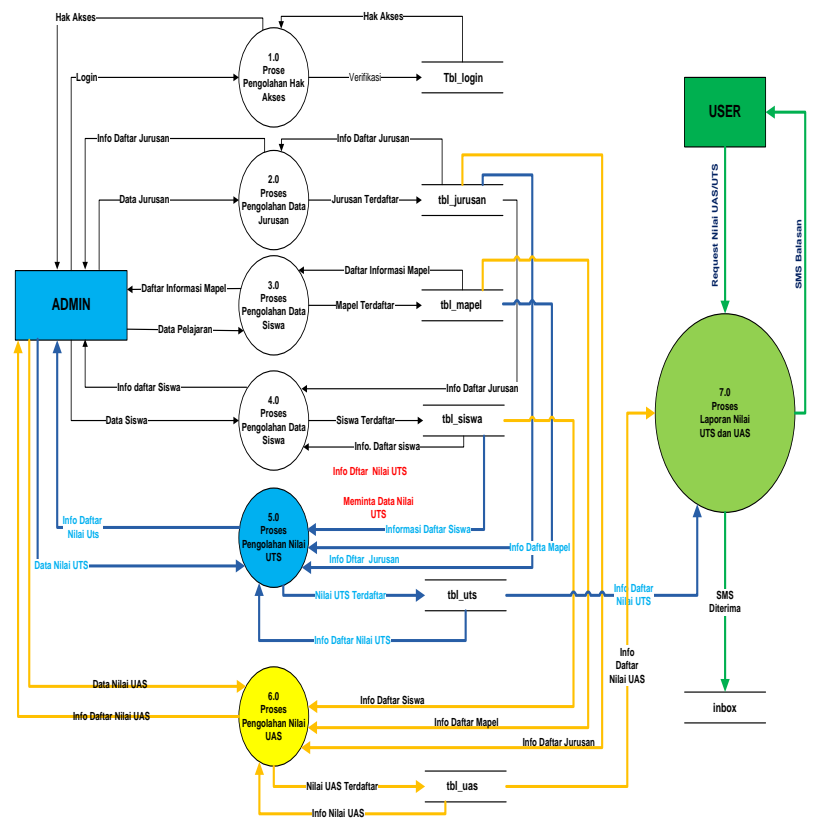

Gambar 12. Diagram Level 1

\section{Entity Relationship Diagram (ERD)}

Rosa dan Shalahuddin, (2013:50), $E R D$ adalah pemodelan awal basis data yang dikembangkan berdasarkan teori himpunan dalam bidang matematika. ERD digunakan untuk pemodelan basis data relasional:

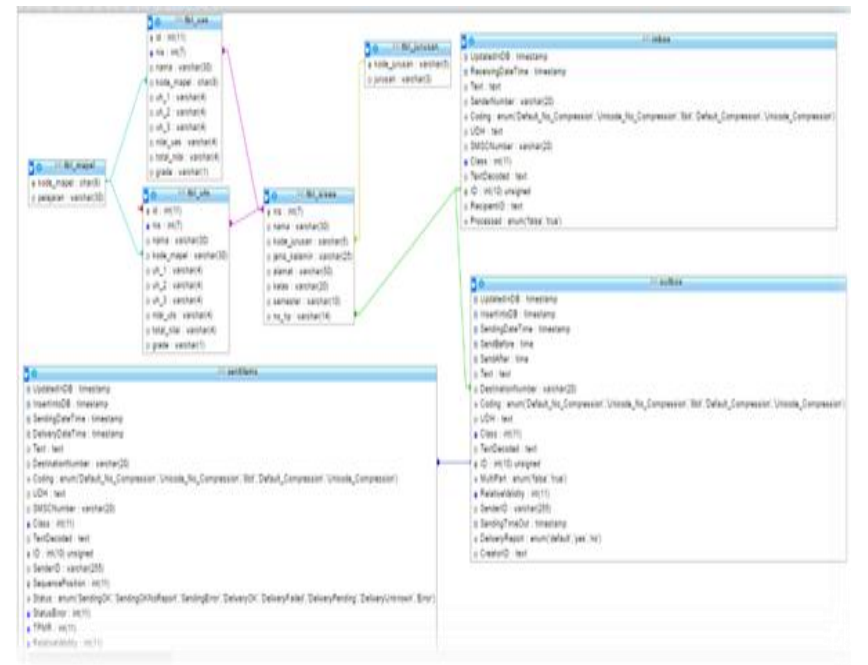

Gambar 13. Relasi Tabel

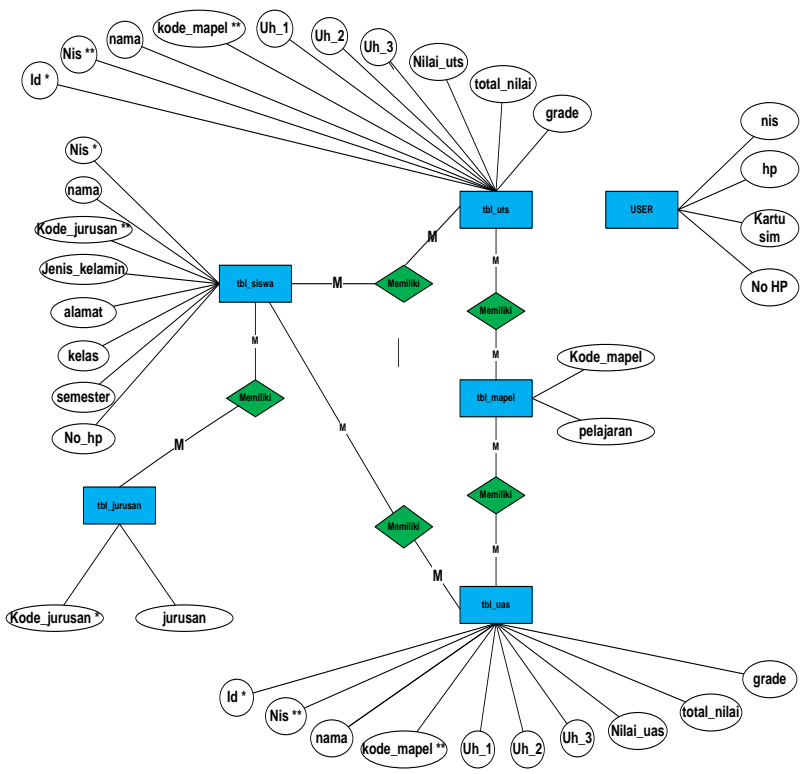

Gambar 14. Erd Notasi

\section{IMPLEMENTASI SISTEM}

Implementasi sistem adalah tahap dimana pemrograman yang dibuat sudah selesai dan akan dipasang dan diuji disesuaikan dengan kebutuhan sistem uyang akan digunakan, berikut merupakan hasil layout dokumentasi gambar penerapan sistem pada Madrasah Aliyah Negeri 1 Halamhera Tengah sebagai berikut: 


\section{Menu Utama}

Menu utama merupakan awal tampilan saat aplikasi digunakan

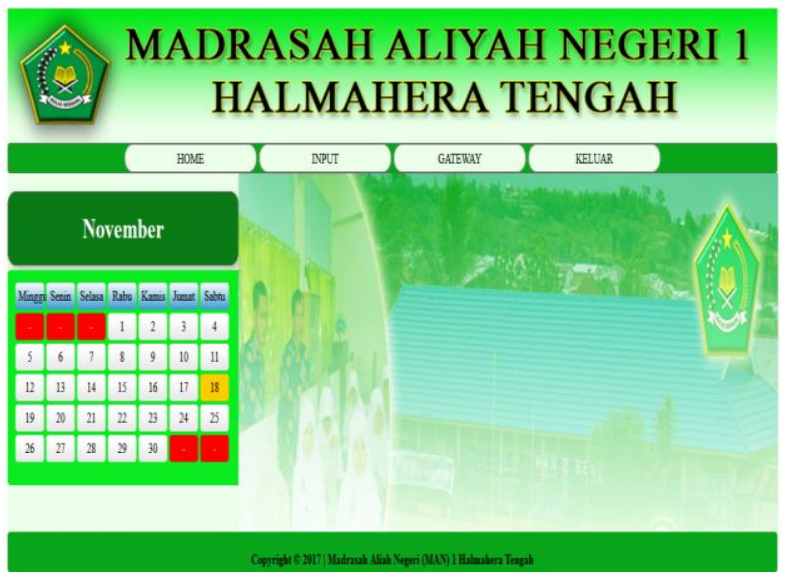

Gambar 15. Tampilan Menu Utama

\section{Halaman Menu Login}

Menu login merupakan menu dimana user akan memulai dan memasukan kode masuk pada sistem tersebut

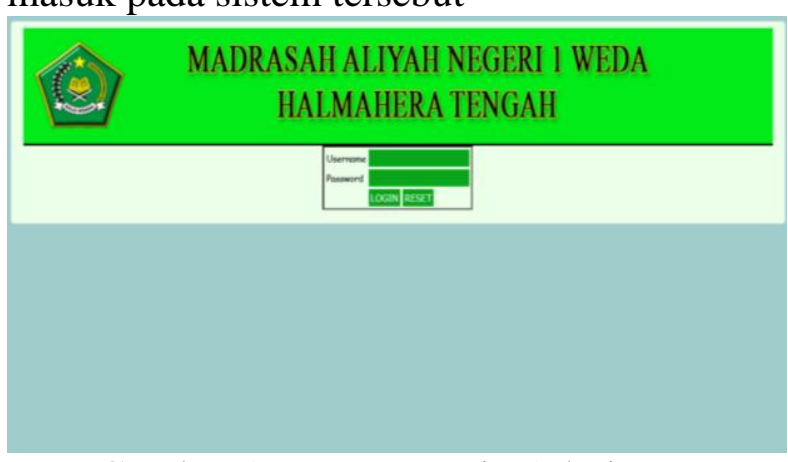

Gambar 16. Menu Login Admin

\section{Halaman Menu Input Data Siswa}

Halaman menu input data siswa merupakan halaman user akan akan menginput data siswa

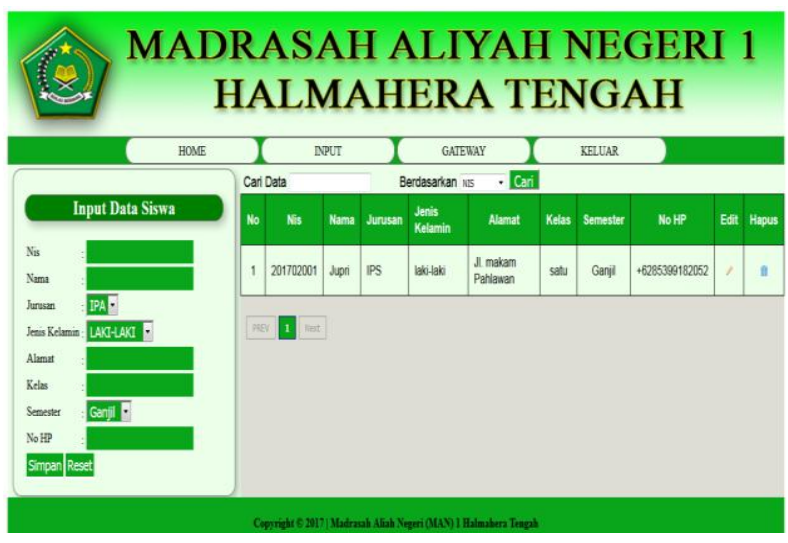

Gambar 17. Menu Input Data Siswa

\section{Halaman Menu Mata Pelajaran}

Menu mata pelajaran merupakan menu dimana user dapat melihat daftar data mata pelajaran yang ada

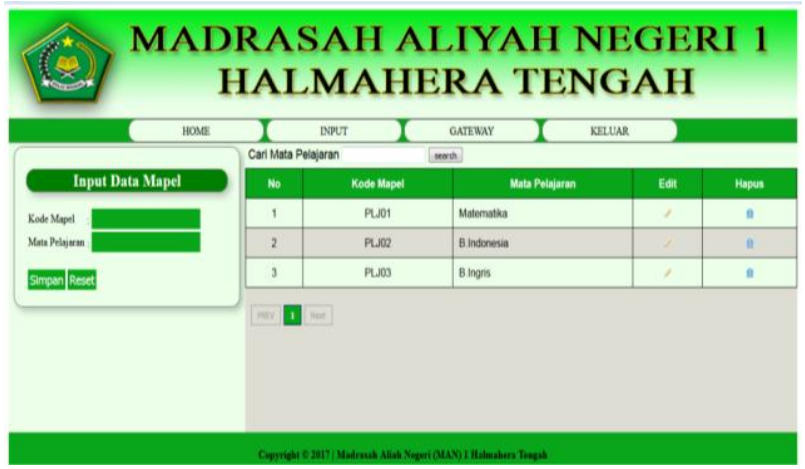

Gambar 18. Menu Mata Pelajaran

\section{Halaman Menu Nilai UTS}

Menu nilai UTS merupakan tampilan dimana user dapat meninput nilai UTS pada sistem

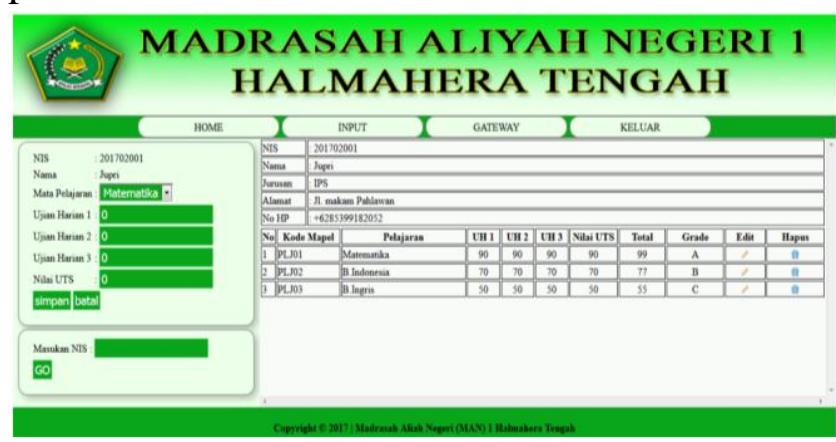

Gambar 19. Menu Nilai UTS

\section{Halaman Menu Nilai UAS}

Menu nilai UTS merupakan tampilan dimana user dapat meninput nilai UAS pada sistem

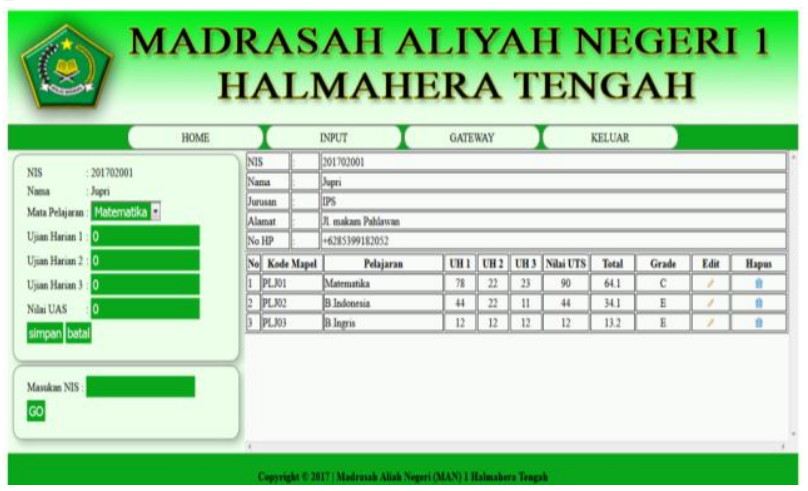

Gambar 20. Menu Nilai UAS 
Halaman Menu Inbox

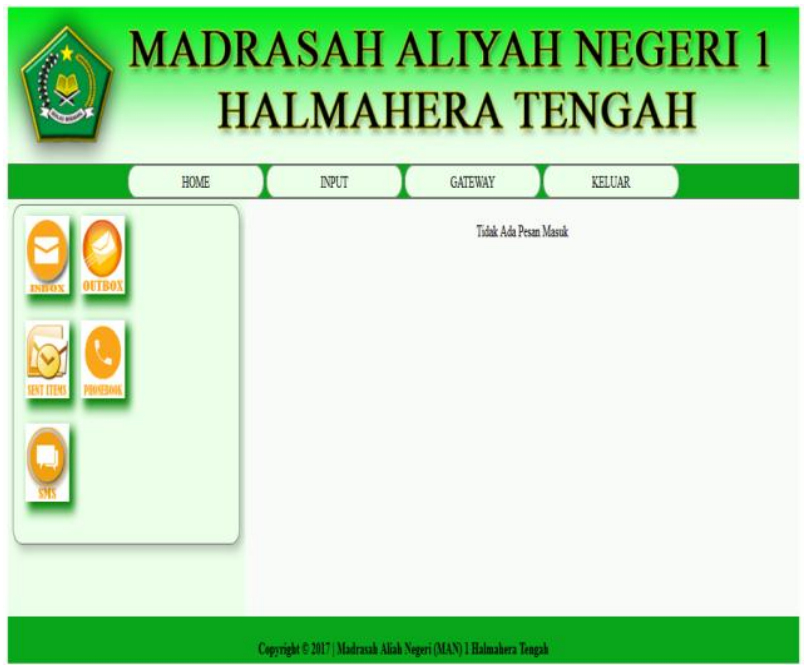

Gambar 21. Menu Inbox

Halaman Menu Outbox

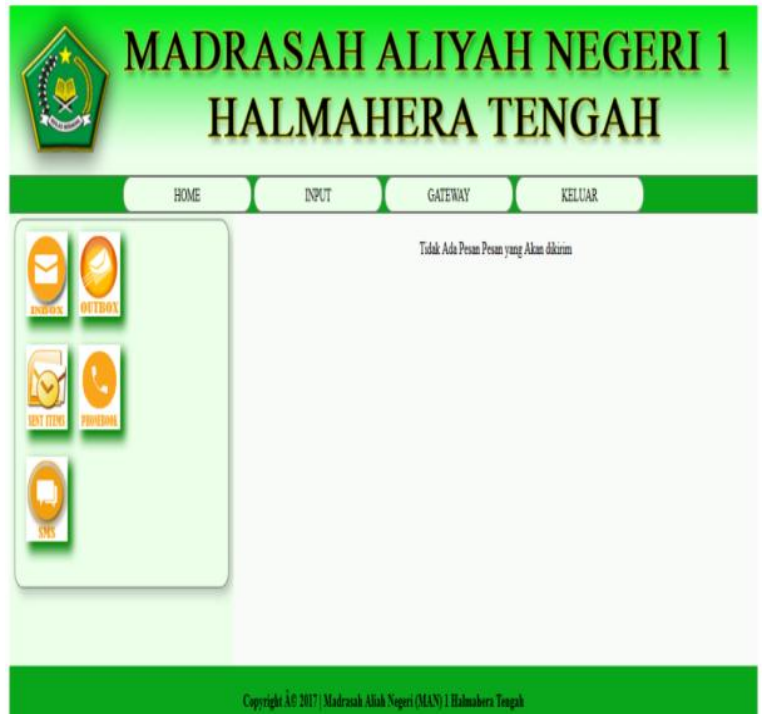

Gambar 22. Menu Outbox

\section{Pengujian Sistem Blackbox}

Pengujian black-box mengidentifikasi jenis kesalahan antara lain kesalahan suatu fungsi, kesalahan suatu antar muka, kesalahan dalam pemodelan data dan kesalahan dalam akses ke sumber data eksternal (Agarwal, B. B.; Tayal, S.P.; Gupta, M., 2010), berikut merupakan hasil pengujian sistem yang didokumentasikan pada tabel berikut:
Tabel 1. Login

\begin{tabular}{|c|c|c|c|}
\hline \multicolumn{4}{|c|}{ Hasil Uji Data Login } \\
\hline $\begin{array}{c}\text { Data } \\
\text { Masukan }\end{array}$ & $\begin{array}{l}\text { Hasil Yang } \\
\text { Diharapkan }\end{array}$ & $\begin{array}{c}\text { Pengama } \\
\text { tan }\end{array}$ & $\begin{array}{c}\text { Kesimpu } \\
\text { lan }\end{array}$ \\
\hline $\begin{array}{l}\text { Username } \\
\text { dan } \\
\text { Password } \\
\text { yang } \\
\text { dimasukan } \\
\text { Valid }\end{array}$ & $\begin{array}{l}\text { Apbila data } \\
\text { Masukan Valid } \\
\text { maka admin } \\
\text { mendapatkan hak } \\
\text { akase aplikasi }\end{array}$ & $\begin{array}{l}\text { Usernam } \\
\text { e dan } \\
\text { Passwor } \\
\text { d sesuai } \\
\text { dengan } \\
\text { data } \\
\text { yang } \\
\text { telah } \\
\text { terdaftar } \\
\text { pada } \\
\text { tabel } \\
\text { login }\end{array}$ & diterima \\
\hline
\end{tabular}

Tabel 2. Penginputan

\begin{tabular}{|l|l|l|l|}
\hline \multicolumn{4}{|c|}{ Hasil Uji Data Form Penginputan } \\
\hline $\begin{array}{c}\text { Data } \\
\text { Masukan }\end{array}$ & \multicolumn{1}{|c|}{$\begin{array}{l}\text { Hasil Yang } \\
\text { Diharapkan }\end{array}$} & $\begin{array}{l}\text { Pengama } \\
\text { tan }\end{array}$ & $\begin{array}{l}\text { Kesimpu } \\
\text { lan }\end{array}$ \\
\hline $\begin{array}{l}\text { Menginput } \\
\text { seluruh } \\
\text { data } \\
\text { jurusan, } \\
\text { mata } \\
\text { pelajaran, } \\
\text { siswa, } \\
\begin{array}{l}\text { UAS dan } \\
\text { UTS }\end{array}\end{array}$ & $\begin{array}{l}\text { Ptoses Penginputan } \\
\text { selesai dilakukan } \\
\text { semudian Klik } \\
\text { simpan dan data } \\
\text { didalam database }\end{array}$ & $\begin{array}{l}\text { Data tidak } \\
\text { akan } \\
\text { tersimpan } \\
\text { apanila } \\
\text { masi ada } \\
\text { field data } \\
\text { yang } \\
\text { belum } \\
\text { diisi }\end{array}$ & $\begin{array}{l}\text { semua } \\
\text { inputan } \\
\text { harus } \\
\text { terisi } \\
\text { maka } \\
\text { database } \\
\text { akan } \\
\text { menerim } \\
\text { a dan } \\
\text { menyim } \\
\text { pan data. }\end{array}$ \\
& & & \\
& & & \\
\hline
\end{tabular}

Tabel 3. Tabel Nilai UTS dan UAS

Hasil Pengujian Laporan Data Nilai UTS dan UAS

\begin{tabular}{|c|c|c|c|}
\hline $\begin{array}{c}\text { Data } \\
\text { Masukan }\end{array}$ & $\begin{array}{l}\text { Hasil Yang } \\
\text { Diharapkan }\end{array}$ & $\begin{array}{c}\text { Pengama } \\
\tan \end{array}$ & Kesimpulan \\
\hline $\begin{array}{l}\text { Format } \\
\text { Pengirim } \\
\text { an } S M S \\
\text { valid }\end{array}$ & $\begin{array}{l}\text { Memperoleh } \\
\text { Informasi } \\
\text { Nilai UTS } \\
\text { dan UAS }\end{array}$ & $\begin{array}{l}\text { Sistem } \\
\text { tetap } \\
\text { menerim } \\
\text { a semua } \\
\text { Pesan } \\
S M S \\
\text { yang } \\
\text { Masuk } \\
\text { kedalam } \\
\text { Aplikasi }\end{array}$ & $\begin{array}{l}S M S \text { balasan } \\
\text { Tegantung Dari } \\
\text { format } \\
\text { Pengiriman } \\
S M S \text {, apabila } \\
\text { format benar } \\
\text { maka balasan } \\
\text { sms berupa } \\
\text { informasi nilai } \\
\text { UTS atau UAS, } \\
\text { tetapi apabila } \\
\text { Format salah } \\
\text { sistem juga tetap } \\
\text { mengirim } S M S \\
\text { balasan berupa } \\
\text { infro format } \\
\text { masukan salah! }\end{array}$ \\
\hline
\end{tabular}




\section{KESIMPULAN}

Berdasarkan penelitian yang dilakukan pada Mandrasah Aliyah Negeri 1 (MAN) Halmahera Tengah maka dapat disimpulkan bahwa 1). Sistem ini dapat membantu pihak sekolah dalam menyampaikan informasi nilai UTS dan UAS dimana saja. 2). Dapat menunjang efektifitas dan pelayanan dalam menginformasikan nilai kepada orang tua dapat melihat informasi nilai dengan sms

Berdasarkan kesimpulan yang diatas maka saran yang dapat diberikan adalah 1). Pihak sekolah dapat mengganti sistem tersebut agar lebih efisien. 2). Ke depan Sistem dapat dikembangkan menggunakan Bahasa Pemrograman berbasis Mobile.

\section{DAFTAR PUSTAKA}

Agarwal, B. B.; Tayal, S.P.; Gupta, M. 2010. Software Engineering \& Testing. Sudbury, Johannes and Bartlett Publishers: Massachusetts.

Agus, 2011, Step by Step Membangun SMS Gateway Menggunakan PHP \& $M y S Q L$. PT Elex Media Komputindo: Jakarta

Arief, M. Rudyanto. 2011, Pemrograman

Web Dinamis Menggunakan PHP \& MySQL. Andi: Yogyakarta.

Nugroho, 2011, Perancangan dan Implementasi Sistem Basis Data. CV. Andi Offset: Yogyakarta.

Fahrudin, Tara. 2012, Notifikasi Jatuh Tempo Tunggakan Kuliah Mahasiswa Berbasis SMS Gateway dan Aplikasi Web. Politeknik Telkom: Bandung.

Sutabri, Tata. 2012, Analisis sistem informasi. Andi: Yogyakarta.

Adiyanto, Suraya, dan Edhy Sutanta. Integrasi Aplikasi Web Dan SMS Gateway Pada Tpi Gempolsari Menggunakan PHP Dan Mysql. 2013,
Jurnal JARKOM Vol. 1 No. 1 Hal 4956, Yogyakarta

A. S., Rosa dan Shalahuddin, M. 2013. Rekayasa Perangkat Lunak Terstruktur Dan Berorientasi Objek. Informatika: Bandung.

Darmawan, Deni dan Fauzi, Nur, Kunkun. 2013. Sistem Informasi Manajemen. PT Remaja Rosdakarya: Bandung

R. A. Sukamto dan M. Shalahuddin, 2013, Rekayasa Perangkat Lunak, Informatika: Bandung.

Danang Sunyoto. 2014, Sistem Informasi Manajemen Perspektif Organisasi. CAPS: Yogyakarta.

Indrajani. 2015. Database Design (Case Study All in One). PT Elex Media Komputindo: Jakarta.

Muharto \& Ambarita, A. 2016. Metode Penelitian Sistem Informasi:

Mengatasi Kesulitan Mahasiswa Dalam Menyusun Proposal Penelitian. Deepublish. Yogyakarta

Heru Supriono, Nugroho Ari Saputro, Rokhmad Andria Pradessya. Rancang Bangun Sistem Informasi Manajemen Presensi Berbasis SMS Gateway (Studi Kasus: SMP Muhammadiyah 1 Kartasura), Proceedings, The 3rd University Research Colloquium (URECOL) 2016, Universitas Muhammadiyah Surakarta 